\title{
Vico y Beckett: las poéticas del work in progress*
}

Fecha de recepción: 15 de octubre de 2018

Fecha de aprobación: 08 de enero de 2019

\section{Resumen}

En contra de las poéticas clásicas como la de Aristóteles y las del clasicismo francés del siglo XVII, Giambattista Vico propone un regreso a los orígenes de lo humano para explorar la naturaleza misma de la poesía comprendida como poeisis, como creación. Poeta significa creador. Los primeros habitantes de la tierra, luego del diluvio universal, fueron gigantes llamados por Vico $i$ bestioni, seres feroces y salvajes, vagabundos errantes que intentaban dar cuenta de su mundo con la suma pobreza de su lengua. El napolitano encuentra en estos seres, un terreno fértil para dar cuenta de la creación sin recurrir a los cánones de las poéticas prescriptivas. Por supuesto, fue un incomprendido en su propia época, pero no lo sería dos siglos más tarde, cuando artistas como Joyce y Beckett asumen su propuesta de pensar a la creación por fuera de los cánones y materializan su pensamiento. De hecho, el primer ensayo y el primer poema escritos por Beckett, tienen que ver con su lectura del napolitano. A lo largo del artículo, se mostrará, entonces, cómo la propuesta de Vico arrojó luces para abrir el espectro de la creación en el siglo XX, que inspiró las apuestas de Beckett en el terreno de las artes, bajo el lema que acompañó a los artistas de esta época: creación como work in progress.

Palabras clave: Vico, Beckett, poéticas, work in progress, creación.

Citar: Rubio Páez, R. (enero-junio de 2019). Vico y Beckett: las poéticas del work in progress. La Palabra, (34), 41-54. 여 https://doi.org/10.19053/01218530. n34.2019.9527

\section{Rafael Rubio Páez}

Filósofo y magíster en Filosofía, Pontificia Universidad Javeriana. Profesor de cátedra en el pregrado de Creación Literaria de la Universidad Central.

rafael.r.rubio@gmail.com

* Artículo de reflexión, derivado de la investigación que giró en torno al trabajo de grado de la Maestría en Filosofía sobre los orígenes de lo humano y la crítica de Vico a la vanidad de los doctos, y alimentado por la actividad docente en el seminario de Poéticas para el pregrado en Creación Literaria de la Universidad Central. 


\section{la palabra}

\section{Vico and Becket: The Poetics of Work in}

\section{Progress}

\section{Abstract}

Against classical poetics such as those of Aristotle and of XVII French Classicism, Giambattista Vico proposes a return to the origins of the human to explore the nature of poetry understood as poeisis, as creation. Poet means creator. The first inhabitants of the earth after the universal flood were giants called $\mathrm{i}$ bestioni by Vico, ferocious wild beings and wandering vagabonds that tried to account for their world with the great poverty of their language. This Neapolitan thinker finds in these beings a fertile ground to think about creation without recurring to the canon of prescriptive poetics. Of course, he was uncomprehended in his time, but he wouldn't be two centuries later when Joyce and Beckett assume the project of thinking about creations outside the canon and materializing their thought. In fact the first essay and first poem written by Beckett deal with Vico. Throughout the article, we will show how Vico's proposal foreshadows the routes of creation in the XXth century, which doubtlessly inspired Beckett's the aesthetic project under the motif of artists of the time: creation as work in progress.

Key words: Vico, Beckett, poetics, work in progress, creation.

En 1929, aparece publicado un ensayo de Samuel Beckett, titulado "Dante ... Bruno. Vico .. Joyce" en un doble número de transition, el 16/17, editada en ese entonces por Eugene Jolas. El origen de este ensayo se da cuando James Joyce invita a su joven amigo Beckett, a participar en un simposio dirigido por Valery Larbaud sobre la obra Work in progress de Joyce, publicada en la misma revista por entregas entre 1927 y 1938. Doce escritores participaron en este simposio, "doce discípulos de Jesucristo": Frank Budgen, Stuart Gilbert, Jolas, MacGreevy, Elliot Paul, John Rodker, William Carlos Williams, Marcel Brion, Víctor Llona, Ro- bert McAlmon, Robert Sage y Samuel Beckett. Los doce firmaron una particular proclama en este número: "Revolución de la palabra" (Cronin, 2012, pp. 102108).

Joyce le sugirió a Beckett el título y los contenidos del ensayo. Por un lado, "estaba al corriente del interés que sentía el joven [Beckett] por Dante. Era uno de los lazos de unión que tenían ambos, y le había dicho que parte de las teorías y de los escritos de Giambattista Vico y de Giordano Bruno habían desempeñado un papel crucial en la estructura básica de la obra [Work in progress]" (Cronin, 2012, p. 106). Beckett conocía a Dante, pero no conocía ni la obra de Bruno ni la de Vico, así que se puso a trabajar en su colaboración y para esto tuvo que indagar por la obra de estos autores. Sin lugar a dudas, como se evidencia en su ensayo, sintió un interés profundo por Vico por tres aspectos principales: su visión de la historia, su teoría de la evolución en tres edades (divina, heroica y humana) y su teoría del lenguaje. En estos tres aspectos, que dan cuenta transversalmente de la obra de Vico, el napolitano se expone, para Beckett, como un innovador y un revolucionario.

Como se evidencia en su ensayo, Beckett hace una lectura juiciosa, rigurosa y comprensiva de 
la Ciencia nueva de Vico, en donde se encuentran expuestos los puntos anteriormente mencionados. Nos concentraremos en dar cuenta de la lectura que hace Beckett de Vico, pues encontramos allí el corazón de una reflexión sobre la poesía cuya proclama, como la transition, es díscola y revolucionaria: "poesía sin poética". Sin duda alguna, tanto Joyce como Beckett comprendieron la propuesta viquiana que sospecha profundamente de las poéticas clásicas atadas a un formalismo que solo se pregunta por la forma y composición de la obra.

El libro de la Ciencia nueva de Vico que lleva por título "Sabiduría poética", es el más grande en extensión constituyendo una parte fundamental de su obra. La razón por la cual lleva este título no es gratuita, sino que tiene un propósito de fondo: dar cuenta de la sabiduría de los primeros habitantes de la tierra, la manera como vivieron y se relacionaron con su mundo, la manera como hicieron las cosas. De ahí que, Vico lleve a cabo una exposición de todo el conjunto de disciplinas que estudia la filosofía y les pone el adjetivo poética. Así, encontramos la metafísica poética, la lógica poética, la moral poética, la física poética, entre otras (Vico, [1744] 2006, pp. 171-398). En su estudio sobre la obra de Vico, Brigante (2008) afirma:
Esta sabiduría se trata del modo que tiene una comunidad primitiva de comprender el mundo en todos sus ámbitos. La sabiduría poética es una forma de pensar que se manifiesta tanto en la intención de explicación del cosmos, como en la conformación de las instituciones que determinan la vida de la comunidad: los primeros hombres piensan poéticamente. (p. 154).

Con las figuras poéticas, por ejemplo, los primeros pobladores del mundo gentil comenzaron a construir formas de expresión naturales que nacieron del cuerpo. La manera como se configuró la lengua poética en las naciones, tiene que ver con la locución poética, pues los primeros pobladores se expresaron a partir de metáforas. Vico indaga, entonces, sobre los orígenes de la lengua, la poesía y el lenguaje y sus íntimas tensiones, y este punto llama particularmente la atención de Beckett, quizás porque desde este lugar Vico opera como un crítico de su tradición.

Quizás uno de los estudios más potentes sobre la obra de Vico, es llevado a cabo por Isaiah Berlin (2000), quien afirma que el napolitano fue más allá que sus contemporáneos precursores dieciochescos del Romanticismo: no supuso simplemente que el poeta crea mundos artificiales, sino que todos los hombres durante el primitivo estadio poético de la cultura conciben el mundo solo de esta manera; que la imaginación desempeña un papel dominante en la conciencia en esta fase de desarrollo, de modo que la canción es la forma natural de expresión antes del habla en prosa. Ello, afirma, constituye una visión de la realidad primitiva, pero no necesariamente supone una valoración de un estadio superior o inferior de la especie humana; es una etapa que puede ser concebida como bárbara, pero no menos valiosa que las sucesivas, aparentemente más civilizadas; más aún, se podría hablar de una suerte de superioridad, quizás, en fuerza pura y vitalidad espontánea (p. 148).

La metáfora y cosas parecidas constituyen una categoría fundamental ya que, en un estadio dado de desarrollo en el que los hombres no pueden auxiliarse de una visión de la realidad, la metáfora es para ellos la realidad misma: ni mero embellecimiento, ni un depósito de sabiduría secreta, ni la creación de un mundo paralelo al mundo real, ni una adición a la realidad o una distorsión de la misma, inofensiva o peligrosa, deliberada o involuntaria, sino el tránsito natural e inevitable de su nacimiento o desarrollo, la única manera posible que los hombres de ese lugar y tiempo concretos, en ese particular estadio de su cultura, tienen para percibir, interpretar y explicar esa realidad. (Berlin, 2000, p. 149). 
Si se tiene en cuenta el estudio que Vico emprende sobre la poesía como forma de expresarse de los primeros hombres, resulta evidente que el napolitano no está haciendo una poética a la manera de Aristóteles, Horacio o Boileau, que se concentran sobre el producto poético y su factura. Es más cercano a poéticas del siglo XX, como la de Valéry o el mismo Beckett, para quienes lo fundamental no es la obra misma, sino los actos del espíritu que llevan a su conformación: "la acción que hace, no la cosa hecha". Esto implica que el napolitano tome distancia de las poéticas clásicas de un modo novedoso, toda vez que no se dirige a dar cuenta de la configuración de una obra, sino que se vuelca sobre el estudio de los orígenes de la lengua poniendo en evidencia que estos son en esencia poéticos.

Reconociendo el deslizamiento que Vico lleva a cabo en relación con la poesía, Beckett (2001) sostiene que el Libro II de la Ciencia nueva elabora "una teoría de los orígenes de la poesía y el lenguaje, la significación del mito, y la naturaleza de la civilización bárbara que debió parecer nada menos que un impertinente ultraje contra la tradición" (p. 116). A la luz de esto, nos interesa examinar la profunda tensión entre poesía y lenguaje, para dar cuenta de una idea de creación que no se limite a sostener que las condiciones canónicas de la poesía suponen la representación de lo real; una idea de creación que se centre en el ejercicio del espíritu productor siempre en acto, que es el ejercicio de un arte vivo como el del bailarín "que a fuerza de negar con su esfuerzo el estado ordinario de las cosas, crea en los espíritus la idea de otro estado, de un estado excepcional -un estado que sería sólo de acción, una permanencia que se haría y se consolidaría por medio de una producción incesante de trabajo" (Valéry, 1998, p. 180).

En la lectura que Beckett hace de Vico, encuentra en el napolitano un antecesor del pensamiento poético del work in progress, de la obra en curso, que encuentra sus representantes en el siglo XX en la obra de poetas como Valéry o Joyce. Nos interesa, entonces, iluminar la lectura que hace el irlandés sobre la obra de Vico, pues esta incursión de Beckett nos ayuda a pensar la creación como un mero ejercicio del espíritu que no se limita a las restricciones de los géneros, sino que explora "el miedo de ese arranque salvaje y rebelde que con violencia aspiraba a que se hiciera el sonido" (Beckett, 1929).

Para esto, en primer lugar haremos una exposición de la manera como Vico aborda la sabiduría poética de los primeros habitantes de la tierra, quienes sienten sin advertir con ánimo perturbado; en segundo lugar, mostraremos cómo en este modo poético de entender el mundo se encarna una lengua pobre y torpe con la que por los efectos de la escasa fortuna estos primeros habitantes se esforzaban en explicarse [...] con la suma pobreza de su lengua, mientras la formaban (Vico, 2006, p. 830).

Gracias a esta comprensión inacabada de la lengua, esperamos ganar un terreno fértil para la elaboración, en tercer lugar, de una teoría de la creación que dé cuenta de la poesía como la acción de ese "arranque salvaje y rebelde que con violencia aspiraba a que se hiciera el sonido".

"En el principio fue el trueno"

Doscientos años después del Diluvio universal, en la tierra seca, el cielo brilla de nuevo:

tronó con rayos y truenos espantosos, como debió suceder al introducirse en el aire por primera vez una irrupción tan violenta. $Y$ entonces unos pocos gigantes, que debían de ser los más robustos, y que estaban dispersos por los bosques en las alturas de los montes tienen allí sus cubiles, asustados y atónitos ante ese gran efecto del que ignoraban su causa, elevaron los ojos y advirtieron al cielo. (Vico, [1744] 2006, p. 377). 
Este escenario en el que se mueven los primeros pobladores de la nueva tierra, opera como un experimento mental de Vico para explorar los orígenes de la lengua y la poesía, así como para exponer su interesante teoría del despliegue de la sociedad humana en tres momentos: divino, heroico y humano. La poesía nace de la curiosidad, que es hija de la ignorancia, punto de partida de la manera como pensaron los primeros hombres. De ahí que, la primera fábula imaginada sea Júpiter, "rey y padre de los hombres y de los dioses, y como un rayo; tan popular, conmovedora y didáctica, que ellos mismos, que la imaginaron, la creyeron y con espantosas religiones [...] le temieron, le reverenciaron y le celebraron" (p.379). Este origen de los auspicios divinos nace de la curiosidad natural que abrió la mente de los primeros habitantes de la tierra, quienes gozaban de una robusta imaginación. Así que, las primeras fábulas fueron inventadas y creídas simultáneamente. La mente de estos gigantes comenzó a operar según el criterio de verdad viquiano: "sólo podemos conocer aquello que hacemos". ¿Cuál es el sentido y el alcance que Vico le da al criterio del verum factum?

Para Vico, la creación se da en dos niveles: divino y humano. Por un lado, la creación divina genera las cosas: "en su purísimo entendimiento, conoce las cosas y, conociéndolas, las crea" (p.76). La mente divina conoce las cosas y, por eso, desde su infinito entendimiento, puede generarlas; la mente humana, por su parte, es finita y precaria, y solo puede crear en la medida en que conoce:

No se nos podría alcanzar, aunque Dios nos lo enseñase, de qué forma el infinito ha descendido a estas cosas finitas: pues es ésta una verdad propia de la mente divina: la de que saber y haber hecho son lo mismo. En cambio la mente humana es finita y formada, y no puede, por ello, entender lo infinito e informe, si bien puede pensarlo; lo que en lengua vernácula diríamos: puó andarle raccogliendo, ma non giá raccôrle tuttel. Pero el propio pensar es confesar que lo que piensas carece de formas $\mathrm{y}$ de límites. Y por eso mismo conocer distintamente es más bien un defecto de la mente que una virtud; pues es conocer los límites de las cosas. La mente divina ve las cosas en el sol de su verdad, esto es, mientras ve una cosa, conoce infinitas cosas junto con la que ve; la mente humana, cuando conoce una cosa distintamente, la ve de noche a la luz de una lámpara, y, mientras la ve, pierde de vista las situadas junto a ella. Siento dolor y no conozco forma alguna del dolor, ningún límite de la enfermedad anímica: el conocimiento es indefinido, y, en tanto que indefinido, digno del hombre; la idea del dolor es vívida y luminosa como ninguna otra. (Vico, 2002, pp. 160-161).

Que el conocimiento humano sea indefinido, abre amplias posibilidades para la comprensión de la poiesis en relación con sus inacabados actos, como la mente de los primeros habitantes de la tierra que vivían según un pensamiento poietico. El verum factum es formulado por Vico con el fin de establecer el principio más importante de su obra: "este mundo civil ha sido hecho ciertamente por los hombres, por lo cual se pueden, y se deben, hallar los principios en las modificaciones de nuestra propia mente humana" (Vico, [1744] 2006, p.331).

Con esta formulación, vemos que el método de Vico implica una concepción del conocimiento per caussas, por cuanto debemos hallar los principios de la historia humana en las modificaciones de nuestra mente. Es definitivo: "ni la información empírica ni la capacidad de razonamiento son suficientes" (Berlin, 2000, p. 67), pues no tienen en cuenta la capacidad creadora del hombre con la que él mismo ha hecho su mundo, y para Vico hay tres fuentes in-

Esta expresión da cuenta de la manera como Vico comprende la mente humana que puede conocer en la medida en que hace, razón por la cual no puede conocer absolutamente todas las verdades. 
agotables que le dan horizonte al conocimiento histórico del hombre: "el lenguaje, la mitología y las antigüedades" (Berlin, 2000, p. 78).

La pregunta que vale la pena plantear en este sentido, es la siguiente: “¿qué tipo de palabras han usado los seres humanos para expresar su relación con el mundo, con los otros y con su propio pasado?" (Berlin, 2000, p. 79). Es interesante la manera como Vico se acerca a este problema, pues si la historia ha sido hecha ciertamente por los hombres, el conocimiento del pasado no puede ser dictado a través de un método abstracto ni empírico; el acceso al pasado solo es posible siempre y cuando hagamos "un enorme esfuerzo [poético] por adentrarnos en las mentalidades [de nuestros antepasados], quienes poseen en exclusiva la clave sobre nosotros mismos" (p. 81).

Los orígenes de lo humano, en la historia poética de Vico, no se pueden comprender desde el ámbito de la reflexión, desde una dimensión meramente racional. En este sentido, el napolitano critica a lo que llama la "vanidad de los doctos", el afán de los hombres ilustrados por conocer el mundo desde su propia realidad reflexiva, dejando de lado toda dimensión sensible e imaginativa. A la luz de esta crítica, Vico elabora un diagnóstico de su presente que lo conduce a la pregunta por los orígenes, a partir de la cual descubre la necesidad de recurrir a la imaginación para acceder a la forma en que los primeros seres contaron su historia: poéticamente. A pesar de la dificultad que esto supone, el napolitano decide dar cuenta de esta época en una suerte de protohistoria que se alimenta de la poesía que, para estas primeras naciones, es vera narratio.

Lógica viene de la voz logos que primero y propiamente significó fábula, que se tradujo al italiano como favela -y la fábula de los griegos se llamó también mythos, de donde viene los latinos $m u$ tus- que en los tiempos mudos nació mental, pues en un lugar áureo dice Estrabón ${ }^{2}$ que había nacido antes de la vocal, o sea, de la articulada: de donde logos significa idea y palabra [...]. Esa primera lengua en los primeros tiempos mudos de las naciones debió comenzar con gestos, actos o cuerpos que tuvieran relaciones naturales con las ideas: por lo que logos o verbum significó también hecho para los hebreos, y para los griegos significó también cosa [...]. Y también mythos llega a significar vera narratio, o sea, hablar verdadero. (Vico, [1744] 2006, § 401).

De lo anterior, podemos colegir que la "lógica" con la que em- pezaron a establecerse las naciones, no obedece a una lógica filosófica o a un universal razonado, sino que el modo como operan las mentes de estas naciones anida en una lógica poética que da cuenta de su propio sentir (Brigante, 2016, p. 155). La formulación de una lógica poética supone que Vico lleva a cabo una indagación de lo que Vico denomina tropos, monstruos y transformaciones poéticas: "los primeros poetas dieron a los cuerpos la existencia de sustancias animadas, dotadas sólo de cuanto ellos eran capaces, o sea, de sentido y de pasión, y así hicieron las fábulas; de modo que toda metáfora así hecha es una pequeña fábula" (Vico, [1744] 2006, § 404). Antes de llegar a tener un lenguaje poético, los primeros habitantes del mundo no tenían un lenguaje articulado como el nuestro. Afirma Berlin (2000) que

actualmente pensamos mediante abstracciones, pero en aquél entonces éstas estaban incluidas en los sentidos, por esta razón ahora nos es naturalmente negado poder entrar en la vasta imaginación de aquellos primeros hombres, cuyas mentes no eran en absoluto abstractas, ni afinadas por nada, ni en nada espiritualizadas, ya que estaban totalmente inmersas en los sentidos, rendidas a las pasiones, enterradas en los cuerpos. (p. 82).

2 El lugar al que hace referencia Vico se encuentra en Geografía, I, 2, 6. 
El gesto, el canto, el baile, todos los lenguajes nacidos del cuerpo y del movimiento de la voz, marcaban un particular estilo de expresión. Este es el lenguaje de los que Vico, aludiendo a la Odisea, llama salvajes polifemos, que se forjan en una lengua pobre de pasiones violentas sin ningún modo de intención comunicativa (Vitiello, 2004, p. 84). Beckett (2001) llama la atención sobre estos seres aterrorizados y los llama vagabundos (p. 116) como sus propias creaciones. El lenguaje de estos vagabundos viene del cuerpo y se forja en el gesto, en el sonido de la voz. Con esto, Vico explora los límites del lenguaje, pues el lenguaje no viene de orígenes cultos y reposados, sino campesinos.

Es digno de observación que en todas las lenguas la mayor parte de las expresiones en torno a cosas inanimadas están hechas a base de transposiciones del cuerpo humano y de sus partes, así como de los sentimientos y las pasiones humanas: como "cabeza", por cima o principio; "frente" y "espalda", delante o detrás; "ojos" de las viñas y esas que se llaman "luces" como elementos de las casas; "boca" toda apertura; "labio", borde de un vaso o de cualquier otra cosa; "diente" de arado, de rastrillo, de sierra, de peine; "barbas", las raíces; "lengua" de mar, "fauces" o "garganta" de ríos o montes; "cuello" de tierra"; "brazos" de río; "mano", para un número pequeño; "seno" de mar, el golfo; "flancos" o "lados", los cantos; "costados" del mar; "corazón" por el medio (llamado umbilicus por los latinos); "pierna" o "pie" de países y "pie" para final; "planta" por base, o sea, fundamento; "carne", "huesos" de frutas; "vena" de agua, piedra mineral; "sangre" de la vid, el vino; "vísceras" de la tierra; "ríen" el cielo, el mar; "silba" el viento; "murmulla" la ola; "gime" un cuerpo bajo un gran peso; y los campesinos del Lacio decían "los campos están sedientos", "los trabajados frutos", "las lujuriosas mieses"; y nuestros campesinos "enamorarse las plantas", "enloquecer las vides", "llorar los surcos", y otros ejemplos innumerables que se pueden recoger en todas las lenguas. (Vico, [1744] 2006, p. 405).

Los primeros habitantes de la tierra tenían un lenguaje poético, "modos de expresión usados por la masa ingenua de la gente en los primeros años de la raza humana, no por los hijos de su edad madura, hombres de letras autoconscientes, expertos o sabios" (Berlin, 2000, p. 80). En su intento por acceder al pasado, Vico descubre que hay tres edades: la de los dioses, la de los héroes y la de los humanos. La primera edad tuvo que ver con gestos dados por la naturaleza como el trueno, que los salvajes primitivos identificaron como Júpiter que les gritaba desde arriba y por eso imaginaron que el cielo era una divinidad. Con este gesto mudo de la palabra de Júpiter, los primitivos comenzaron a creer en los auspicios. En este estadio, el lenguaje surge como una imagen del mundo que es absolutamente natural y tiene que ver con sus orígenes divinos.

En segundo lugar, encontramos que en el ascenso de la humanidad hacia los tiempos reflexivos, las figuras que para los doctos configuran el discurso de la poética, para los de mente poética son vera narratio: fábulas y mitos que aún no se organizan en un entramado conceptual garante de la realidad que nos proporciona el lenguaje articulado. Con la metáfora, el símil, entre otras imágenes poéticas, como el ejemplo, Vico muestra la inversión de la lógica abstracta en la mente de los primitivos, con lo cual configura lo que él denomina lo imposible creíble: esta generación de la poesía finalmente nos es confirmada por esta propiedad eterna suya: que su materia propia es lo imposible creíble, en cuanto es imposible que los cuerpos sean mentes (y, sin embargo, se creyó que el cielo tronante era Júpiter). (Vico, [1744] 2006, § 383).

Este nivel del discurso poético, por ejemplo, no podría estar presente en una poética como la de Aristóteles, para quien el material primario de la poesía es la mímesis de acciones y de vida, para lo cual es necesario un relato que sea posible y creíble: "en la tragedia se dedican 
a nombres de personas que han existido y la causa es que lo posible es convincente; en efecto, lo que no ha sucedido, de ningún modo creemos que sea posible, pero lo que ha sucedido es evidente que es posible, pues no habría sucedido si fuera imposible" (2003, 1451b). Lo imposible no tiene sentido en la narrativa de la mímesis aristotélica, pues no es convincente, mientras que para la edad heroica viquiana no hay otra realidad que la que tienen enterrada en sus cuerpos.

En el tercer estadio, los doctos comenzaron a pensar a través de abstracciones del lenguaje articulado. "Y ahora heme aquí, con mi puñado de abstracciones, entre las cuales destacan especialmente: una montaña, la coincidencia de los contrarios, la inevitabilidad de la evolución cíclica, un sistema de poética, y la perspectiva propia en el mundo del work in progress [...]" (Beckett, 2001, p. 113). Como un work in progress, la humanidad gira en torno, y con fatal monotonía, a esa montaña, a esa coincidencia de los contrarios, a esa imposibilidad de evitar la evolución cíclica, a ese sistema de poética, a esa perspectiva propia en el mundo del work in progress.

Así mismo, en lo humano conviven las tres edades girando con fatal monotonía: la divina, dominada por los sentidos a través de los cuales se percibieron las primeras señales mudas a través de los rayos del cielo; la heroica, con su lenguaje poético saturado de metáforas, símiles, ejemplos creados por la imaginación innata de las mentes de este periodo; y la humana, que nace con un lenguaje directo, prosaico, lejano de los recursos proporcionados por un pensamiento poético que, para Vico, significa primitivo. A nuestro autor, le interesa el lugar de lo primitivo o de lo campesino como un escenario en el que el lenguaje se expande.

Vico afirma que de la misma manera que el campesino todavía piensa que sus derechos, digamos sobre un trozo de tierra, surgen de las palabras efectivas del contrato -porque las palabras tienen en sí mismas un poder compulsivo-, en las sociedades primitivas actos importantes como la liberación de esclavos, la toma de posesión de una propiedad, la venganza por una injuria, eran actos realizados por medio de las palabras, las cuales poseerían en sí mismas la fuerza de los actos originales. Agamenón y Jefta (quienes pertenecieron a la edad de los dioses) sacrificaron a sus hijas porque la simple acción de pronunciar los juramentos tenía la fuerza de una causalidad natural y las palabras cambiaban de manera inmediata (y eran reconocidas como actos que consistían precisamente en eso) el status quo, simplemente por el hecho de haber sido pronunciadas. (Berlin, 2000, p. 89).

El lenguaje y el mito son dos vías para acceder al conocimiento de este pasado donde no había un juicio reflexionante, sino meras creaciones poéticas. Nos interesa este lugar propuesto por Vico, pues consideramos que es tremendamente sugerente para abordar los problemas de la creación en el mundo contemporáneo, toda vez que toma distancia de los cánones formalistas de teorías poéticas que cierran las posibilidades de pensar en un escenario amplio y complejo para las artes. El mito, comprendido a la luz de Vico, nos instala entonces en un lenguaje mudo que es propio del creador, quien no procede a partir de la abstracción de los géneros, sino del primitivo estado de las cosas y del mundo. "Los mitos son formas de ver, de comprender y de reaccionar ante el mundo" (Berlin, 2000, p. 90), pues "las mitologías, no forzadas y retorcidas, sino directas, fáciles y naturales [...] son historias civiles de los primeros pueblos, los cuales se halla que fueron en todo y naturalmente poetas". (Vico, [1744] 2006, § 352).

En este punto, es claro que Vico toma absoluta distancia de las poéticas que encuentran en Aristóteles un punto de referencia, pues mientras para el estagirita el corazón de la tragedia es la composición de los 
hechos de la fábula, para Vico esta es la vida misma. El napolitano no recurre a la mímesis para dar cuenta de la creación poética. No hay narración, no hay guion. Como bien lo apunta Brigante (2016), el mito tiene que ver con la formación de las creencias de la comunidad, con la realidad misma, no con su narración. De ahí que, Vico con la sabiduría poética identifique un terreno fértil para la poesía como forma primaria de toda lengua, pues "poética entendida como adjetivo de sabiduría es, precisamente, una manera originaria de entender el mundo. La poética de los primitivos es inmediata e irreflexiva" (Brigante, 2016, p. 158), es poesía: "Lugar de los restos donde antaño en lo oscuro de tarde en tarde un resto relucía" (Beckett, 2001, p. 25).

\section{Una lengua pobre}

Para Vico, la poesía tiene valor histórico y real por la evidencia de la imagen fantástica que la genera, así como la historia de los orígenes es propiamente historia poética (véase Patella, 2005, p. 37). Con esta tesis, que pone al napolitano a las antípodas de las poéticas clásicas, podemos afirmar que la primera historia de nuestras naciones es la historia poética que Vico ([1744] 2006) narra a lo largo de la metafísica, la lógica, la moral, la política, la economía poéticas, "pues habiendo sido los poetas ciertamente anterio- res a los historiadores vulgares, la primera historia debe ser la poética" (§ 813). La filosofía viquiana asume a la poesía como fundamento de la realidad misma. La verdad poética garantiza la libertad de la creación poética, pero además su plena autonomía. Este es el carácter del universal fantástico que Vico configura a partir de la sabiduría poética: "con esta comprensión del imposible creíble se puede sostener que la poesía no se establece sobre la base de la efectualidad histórica, ni sigue el orden de los eventos como vienen regulados por el pensamiento científico" (Patella, 2005, p. 41), y desde este punto los universales poéticos viquianos exploran lo real y lo hacen cognoscible (Sini, 2007, p. 58).

Lo interesante de los caracteres poéticos o géneros fantásticos, es que nos ponen ante un límite de la razón humana que está presente en las expresiones poéticas de nuestros antepasados, quienes poseían un vocabulario mental "comido por la pobreza" en el "que las torpezas e inconveniencias son [...] efectos de la escasa fortuna con la que se esforzaban en explicarse [...] con la suma pobreza de su lengua, mientras la formaban" (Vico, [1744] 2006, § 830). Por esto, es importante la vuelta al pasado, porque allí encontramos lo que somos en su modo de darse más primitivo, como bárbaros que no entienden el mundo a través del intelecto, sino del uso de la fantasía, pues "el habla heroica [...] fue un habla por semejanzas, imágenes, comparaciones, nacida de la ignorancia de los géneros y de las especies, que se necesitan para definir las cosas con propiedad, $\mathrm{y}$, en consecuencia, nacida por una necesidad natural común a pueblos enteros" (§ 832).

Para Vico, la realidad poética es una realidad autónoma y el carácter de la poesía, como ya se dijo, es vera narratio. De ahí que, Vico no indague por la legitimidad de la poesía como una "ingeniosa expresión popular de conceptos filosóficos, ni como un divertido entretenimiento social, ni como una ciencia exacta al alcance de cualquiera que tenga la receta" (Beckett, 2001, p. 123). Por el contrario, para Vico la poesía nace de la curiosidad que es hija de la ignorancia. "Los primeros hombres tuvieron que crear materia con la fuerza de su imaginación, y poeta significa creador" (Beckett, 2001, p. 123).

Las sentencias, comparaciones $\mathrm{y}$ descripciones que encontramos en la poesía, no son producto de un filósofo reposado, culto y diestro (Vico, [1744] 2006, § 828). "Las costumbres de los héroes homéricos son propias de niños por la ligereza de sus mentes, de mujeres por la robustez de la fantasía, de jóvenes violentísimos por el ferviente bullir de la cólera, como más arriba se ha demostrado, 
$y$, en consecuencia, resulta imposible que un filósofo pudiera fingirlas con tanto éxito y naturalidad" ( $\$ 829)$. La poesía encarna una forma sentida, imaginada y bárbara de la lengua que es pura producción que toma su materia de la carne del mundo de la vida, y así cobra fuerza e intensidades en la medida en que avanza en sus actos.

Vico entiende que la mente de los primitivos no articulaba el sentido con los alcances de una inteligencia de orden puramente objetiva y racional. "Júpiter no era un símbolo: era terriblemente real" (Beckett, 2001, p. 127). Lo que Vico ve allí es una exploración de lo real por una lengua que intenta profundizar en la vida de un pueblo y hacerla cognoscible. Quizás lo que Vico ve en las primeras formas de la poesía es un uso pobre del lenguaje donde las palabras están vivas y viven a través de una salvaje economía de jeroglíficos, imágenes y gestos. "El lenguaje está ebrio. Las mismas palabras están vaciadas y en efervescencia" (Beckett, 2001, p. 130). Poeta es aquel que se instala en el mundo y lo materializa en un lenguaje indirecto:

Shakespeare emplea palabras gruesas, pringosas para expresar la corrupción: Duller shouldst thou be than the fat weed that rots itself in death on Lethe wharf. Oímos chapotear el cieno a través de la descripción del Támesis en Great Expectations de
Dickens. Esta escritura que encuentran ustedes tan oscura es la quintaesencia de lenguaje, pintura y gesto, con toda la inevitable claridad de la vieja articulación [...]. Aquí las palabras no son las cultas contorsiones de la tinta de los impresores del siglo XX. Están vivas. Se abren paso sobre la página, $\mathrm{y}$ brillan y arden y se apagan y desaparecen. (Beckett, 2001, pp. 131-132).

Como la lengua de los gigantes viquianos que doscientos años después del diluvio pudieron poblar la nueva tierra, la lengua de los poetas se forja bajo el signo de una dimensión primitiva y campesina. Germina, madura, muere, pero no muere por haber vivido. Es una lengua que produce palabras con una materialidad plástica, que hace posible que el sentido adquiera la forma de una imagen: "cuando el sentido es dormir, las palabras se van a dormir [...]. Cuando el sentido es bailar, las palabras bailan" (Beckett, 2001, p. 130).

\section{Vico y Beckett: cómo decir}

Locura visto eso eso cómo decir esto eso esto esto de aquí todo ese esto de aquí locura dado todo eso visto - locura visto todo ese esto de aquí sólo sólo cómo decir ver entrever creer entrever querer creer entrever locura sólo querer entrever qué

Cómo decir

\section{Samuel Beckett}

El poeta no goza de una sabiduría profunda como la del filósofo. Es ignorante y esta es hija de la curiosidad. El poeta siente una profunda curiosidad por el mundo. Esta es la manera como los primitivos comenzaron a forjar unos modos de expresión no racionales, indefinidos y descompuestos: "fue necesario que la lengua heroica en su comienzo estuviese sumamente descompuesta; esta es una gran fuente de la oscuridad de las fábulas" (Vico, [1744] 2006, § 446).

No existe dualismo entre poesía y lenguaje, pues el lenguaje no es ni un "simbolismo culto y convencional ni un regalo de los dioses" (véase Beckett, 2001, p. 124). En aras de forjar una racionalidad poética, Vico comprende que las formas mudas de la expresión son también lenguaje: "a partir del asombro producido por los primeros rayos en los hombres, [nació] la primera interjección con referencia a Júpiter, formada con la voz ipa!, y después quedó 
redoblada en ipape!, interjección de asombro" (Vico, 2006, $\S 448$ ), y que su evolución "a través de la poesía hasta ser un vehículo altamente civilizado, rico en términos abstractos $\mathrm{y}$ técnicos, fue tan poco fortuita como la evolución de la sociedad misma" (Beckett, 2001, pp. 124-125). Todo lenguaje tiene una dimensión poética y precategorial, pues, parafraseando a Nietzsche (2012), todo lenguaje es un compedio de metáforas olvidadas (p. 28).

De ahí que, Vico "afirme la espontaneidad del lenguaje y niegue el dualismo poesía $\mathrm{y}$ lenguaje. Del mismo modo la poesía es el fundamento de la escritura" (Beckett, 2001, p. 126). Esta tesis ilumina las posibilidades del lenguaje como una materia creadora en sentido amplio. No solo es lenguaje aquello que simbólicamente representa convenciones; alfabetizar no quiere decir exclusivamente saturar de significado las palabras y las cosas; se trata de descomponer el lenguaje y echar mano de sus residuos. Un ejercicio de descomposición es lo que sugiere Vico.

"Los orígenes fabulosos, imaginados, inventados y creídos por los primeros habitantes de la tierra, no son representación de lo real ni mímesis de acciones y de vida. No hay, pues, composición narrativa, ya que esto implicaría una triple operación intelectual: la construcción de un mensaje de significado universal, la preparación de una forma fabulosa, y un ejercicio de considerable dificultad técnica para unir ambas cosas" (Beckett, 2001, p. 127), y recordemos, una vez más, que los primeros habitantes son primitivos vagabundos sin cobijo de las leyes de las poéticas reflexionantes. Inocentes, ante todo.

Los primitivos comenzaron a pensar como poetas poseídos por la vida: "ellos, por su robusta ignorancia, lo hacían a base de una fantasía muy corpulenta, y porque era muy corpulenta, lo hacían con una asombrosa sublimidad, tal y tanta, que les perturbaba hasta el exceso a ellos mismos, que fingiéndolas, las creaban, por lo que fueron llamados poetas, que en griego suena igual que creadores" (Vico, 2006, p. 376).

Vico nos ha dado profundos elementos para elaborar una cuidadosa teoría de los orígenes del lenguaje y la poesía, romper con los dualismos poesía y lenguaje, y establecer las condiciones de posibilidad de la creación poética. Como vimos al comienzo de este texto, Beckett llega a conocer la obra de Vico por una sugerencia que le hace Joyce para el ensayo que prepararía para su colaboración en el simposio sobre Work in progress, cuya estructura es tremendamente viquiana. Desde entonces, Vico acompañó a Beckett, quien soportó cada vez menos las palabras (véase Deleuze, s.f., p. 9), y a la manera del creador viquiano de los primeros tiempos de la tierra se interesó cada vez más por lo que se esconde en el fondo del lenguaje, ese lugar primigenio en el que ya no hay palabra sino meros residuos. En su texto "El agotado" (s.f.), Gilles Deleuze reflexiona sobre dos obras que Beckett presentaría en televisión en la década de los ochenta: Quad y Nach und Träume. Lo interesante de ambos audiovisuales es la absoluta toma de distancia de Beckett frente a la palabra. Deleuze identifica este punto en su ensayo y hace una lectura que ilumina la relación que Beckett seguiría teniendo con Vico 56 años más tarde. Sin duda alguna, lo que interesa a Deleuze de Beckett, es su manera de comprender la palabra como un material sólido, rígido, con un compuesto de partículas difíciles de romper: "Las palabras están tan cargadas de cálculos y significaciones, y también de intenciones y recuerdos personales, de viejos hábitos que los cimientan, que su superficie se vuelve a cerrar apenas abierta" (Deleuze, s.f., p. 9).

Mientras que en música o en pintura la superficie es penetrable, maleable, transgredible, la palabra insiste en adherirse a los particulares o a los universales, "les falta esa puntuación de deshicencia, ese desligamiento que viene del mar de fondo propio del arte" (Deleuze, s.f., 
p. 10). En este sentido, Deleuze nos ayuda a ver, sin que sea su intención, la profunda tendencia viquiana de Beckett, quien encuentra en la indagación del napolitano sobre los orígenes de lo humano lo que él mismo encontró en la televisión con Quad y Nach und Träume: la inferioridad de las palabras "cuando [éstas] se perforan y se dan la espalda a sí mismas para mostrar su propio exterior. Música propia de la poesía leída en voz alta y sin música" (Deleuze, s.f., p. 10). El talante originario de la poesía es la intensidad de un acto del espíritu como el del bailarín o el rapsoda que nunca cesa de hacerse, un acto de una fuerza desgarradora que produce una imagen, que hace la imagen sonar. De la interesante lectura que lleva a cabo Deleuze de estas dos obras de Beckett, nos interesa el hecho de que allí nadie tiene voz para hablar y nadie oye. Podríamos decir que todo está mudo, como los primitivos de Vico.

El insomne de Nach und Traäume se prepara para lo que tiene que hacer. Está sentado, las manos apoyadas sobre la mesa, la cabeza apoyada sobre las manos, un simple movimiento de manos que se colocasen sobre la cabeza, o al menos se soltasen, es una posibilidad que sólo puede aparecer en un sueño, como una banqueta voladora... Pero ese sueño hay que hacerlo. El sueño del agotado, del insomne, del abúlico, no es como el sueño que se da al dormir, que se hace solo, en la profundidad del cuerpo y del deseo; es un sueño del espíritu, que debe ser hecho, fabricado. Lo "soñado", la imagen, será el mismo personaje en la misma posición de sentado, invertido, perfil izquierdo en vez del perfil derecho, y sobre el soñador; pero para que las manos soñadas surjan como imagen, será necesario que otras manos, de mujer, revoloteen y levanten la cabeza, le den de beber de un cáliz, la limpien con un trapo, de modo que, con la cabeza ahora levantada, el personaje soñado pueda tender sus manos hacia una de las que condensan y dispensan la energía en la imagen. Esta imagen parece alcanzar una intensidad desgarradora, hasta que la cabeza vuelve a caer sobre tres manos, mientras que la cuarta se posa sobre el cráneo. Y cuando la imagen se disipa, se creería oír una voz: lo posible está realizado: "está hecho, he hecho la imagen”. (Deleuze, s.f., p. 9).

Pero como en Vico, en el teatro de Beckett, que es poesía hecha imagen, poesía visual, "ninguna voz habla". Lo que tiene que hacer el insomne es reposar y estar en silencio, "ojos cerrados bien abiertos". El ejercicio del espíritu del rapsoda beckettiano es intenso, en la medida en que consiste precisamente en instalarse en la realidad y profundizar en ella hasta alcanzar orígenes que perforan la palabra. Esto es un work in progress: un obstinado rigorismo en el que la mente y el espíritu siempre en acto se ejercitan haciendo la imagen. "No puede moverse, sentado, con la cabeza vacía sobre manos atrofiadas, ojos cerrados bien abiertos [...]. Es de noche y va a soñar" (Deleuze, s.f., p. 8).

El insomne tiene que preparar el sueño, tiene que hacerlo y ya agotado, como el lenguaje que se agota, no queda más que "la voz de un hombre que tararea y canturrea las últimas cadencias del humilde estribillo conducido por la música de Schubert, Vuelvan dulces sueños, una vez antes de la desaparición de la imagen, una vez luego de su desaparición". De esta manera, Beckett logra volcar el lenguaje sobre sus propios orígenes mudos, sordos, descompuestos; perfora la palabra, la hiere y se encuentra de cara con los primitivos de Vico. Su conciencia fracturada, extraviada, errante, vagabunda, descompuesta. A falta de palabras, quedan sus residuos, como en el El innombrable:

a falta de palabras, es lo único que tengo, y aun así, van escaseando, la voz se altera, está bien, conozco eso, debo conocerlo, será el silencio, a falta de palabras, lleno de murmullos, de gritos lejanos, el previsto, el de la escucha, el de la espera, la espera de la voz, los gritos se calman, como todos los gritos, lo que quiere decir que se callan, los 
murmullos cesan, abandonan, la voz vuelve, vuelve a intentar, no hay que esperar que desaparezca, que no haya voz, que no quede más que un residuo de murmullos, de gritos lejanos, hay que intentar de prisa con las palabras que quedan, ¿intentar qué?, lo ignoro, no importa, nunca lo supe, intentar que ellos me conduzcan a mi historia, las palabras que restan, mi vieja historia, que olvidé, lejos de aquí, a través del ruido, a través de la puerta, en el silencio, eso debe de ser, es de- masiado tarde, quizá sea demasiado tarde, quizá ya está hecho [...]. (Beckett, 2010, p. 182).

Con este residuo de murmullos, queremos ver en Beckett al artista que Vico vio en sus primitivos. Es un escenario potente que se agota en el marco de una teoría poética, pues huye al concepto y apuesta por la vida, sin más, por la vida. Este escenario es un espacio de investigación, en la medida en que se propone como un ensayo, como un cons- tante e incesante trabajo del espíritu productor que hace la vida posible "en los días y noches molidos ciegamente", "en los días felices gris de escarcha", "sobre mi vida mía que me persigue y huye", "errando y dando vueltas lejos de toda vida", "sin voz entre las voces", "qué haría yo sin este rostro sin preguntas", "qué haría yo, yo haría como ayer como hoy" (Beckett, 2001, pp. 81-84), como esa voz que vuelve, a intentar, quedarse, como las palabras que restan.

\section{Referencias}

Aristóteles. (2003). Artes poéticas. Madrid: Visor.

Beckett, S. (2001). Dante ... Bruno. Vico .. Joyce. En: Detritus. Barcelona: Tusquets.

Beckett, S. (2010). El innombrable. Madrid: Alianza.

Berlin, I. (2000). Vico y Herder. Madrid: Cátedra.

Brigante, A. (2008). La razón poética en Giambattista Vico. Universitas Philosophica, 51(25), 181-193.

Brigante, A. (2016). Sabiduría poética y poética en Giambattista Vico. Universitas Philosophica, 33(66), 151-169.

Cronin, A. (2012). Samuel Beckett. El último modernista. España: La uÑa RoTa.

Deleuze, G. (s.f.). El agotado. Recuperado de https://edespecial8.files.wordpress.com/2014/07/gillesdeleuze-el-agotado.pdf

Nietzsche, F. (2012). Sobre verdad y mentira en sentido extramoral y otros fragmentos de filosofía del conocimiento. Madrid: Tecnos. 
Patella, G. (2005). Giambattista Vico. Tra Barocco e Posmoderno. Milano: Mimesi.

Sini, S. (2007). Osservazioni sul passagio dal "ri-uso rituale" al "ri-uso mondano" nell'opera di Vico. En: Edoardo Esposito (ed.), Sul ri-uso. Pratiche del testo e teoria della letteratura (pp. 25-60). Milano: FrancoAngeli.

Valéry, P. (1998). Teoría poética y estética. Madrid: Visor.

Vico, G. (2002). Obras. Oraciones inaugurales y La antiquísima sabiduría de los italianos. Barcelona: Anthropos.

Vico, G. (2006). Ciencia nueva. Madrid: Tecnos. 